\title{
Canalis Sinuosus and radiographic procedures in the region of anterior maxilla
}

\begin{abstract}
- Jun Ho Kim DDSDepartment of Oral Radiology, School of Dentistry, University of São Paulo, São Paulo, Brazil • Reinaldo Abdala Júnior MSc Department of Oral Radiology, School of Dentistry, University of São Paulo, São Paulo, Brazil • Eduardo Massaharu Aoki MSc Department of Oral Radiology, School of Dentistry, University of São Paulo, São Paulo, Brazil • Marina Gazzano Baladi PhD Department of Oral Radiology, School of Dentistry, University of São Paulo, São Paulo, Brazil • Arthur Rodriguez Gonzalez Cortes PhD Department of Oral Radiology, School of Dentistry, University of São Paulo, São Paulo, Brazil - Plauto Christopher Aranha Watanabe PhD Department of Stomatology, Public Oral Health, and Forensic Dentistry, Ribeirão Preto Dental School, University of São Paulo, Ribeirão Preto, Brazil • Emiko Saito Arita PhD Department of Oral Radiology, School of Dentistry, University of São Paulo, São Paulo, Brazil
\end{abstract}

ABSTRACT | The Canalis Sinuosus (CS) is known as an anatomical variation of anterior superior alveolar nerve being a neurovascular bundle. Frequently, the anterior maxillary region receives surgical interventions of different specialties. The knowledge concerning anatomical structures in this region is crucial to reach predictable and safe surgical procedures. The overlapping of anatomical structures in conventional imaging examinations has a limit in observing neurovascular canal, such as the CS. Thus, Cone Beam Computed Tomography (CBCT) images may give a great support in preoperative planning, since it allows the three-dimensional reconstruction of the anatomical details of its structures. In this report, the author describes an implant rehabilitation that may have possibly injured the anterior superior alveolar nerve.

DESCRIPTORS | Anatomic Variation; Cone-Beam Computed Tomography; Dental Implants; Hard Palate; Oral Diagnosis; Oral Surgery.

RESUMO Canal Sinuoso e procedimentos radiográficos na região anterior da maxila • O canal sinuoso (CS) é conhecido como uma variação anatômica do nervo alveolar anterior superior, sendo um canal de feixe vásculo-nervoso. Frequentemente a região anterior da maxila recebe intervenções cirúrgicas de diferentes especialidades. O conhecimento a respeito das estruturas anatômicas presentes nessa região é de suma importância para se alcançar procedimentos cirúrgicos mais seguros e previsíveis. A sobreposição de estruturas anatômicas nos exames de imagens convencionais é uma limitação para se observar o canal neuro vascular como o CS. Assim, as imagens de Tomografia Computadorizada por Feixe Cônico (TCFC) são de grande auxílio no planejamento pré-cirúrgico, pois permitem avaliar os detalhes das estruturas anatômicas em três dimensões. Neste estudo, os autores relatam um caso de reabilitação por implante que poderia ter lesionado o nervo alveolar superior anterior.

DESCRITORES | Variação Anatômica; Tomografia Computadorizada de Feixe Cônico; Implantes Dentários; Palato Duro; Diagnóstico Bucal; Cirurgia Bucal.

CORRESPONDING AUTHOR
- Jun Ho Kim Discipline of Oral Radiology, Department of Stomatology, School of Dentistry, University of Sao Paulo - Avenida Professor Lineu Prestes, 2227, Butantã São Paulo, SP, Brazil • 05508-000 Email: jun.kim@usp.br

- Received May 23, 2015 • Accepted Jun 30, 2015

- Dol http://dx.doi.org/10.11606/issn.2357-8041.clrd.2015.122122 


\section{INTRODUCTION}

The Canalis Sinuosus (CS) is known as an anatomical variation of Anterior Superior Alveolar (ASA) nerve. The ASA nerve supplies the incisors and canines, as well as adjacent soft tissues. ${ }^{1}$ The CS was first described by Jones, as the nerve and blood vessels that leave the infraorbital nerve through a bone canal about $2 \mathrm{~mm}$ in diameter beside the nasal cavity. ${ }^{1}$ Neves et al. reported that, during a bone graft surgical procedure in the anterior maxilla, the periosteum was dissected and the innervation of the CS could be observed and tested, confirming that there was a neurovascular bundle inside this canal, and therefore, it was not a simple nutrient canal. ${ }^{2}$

Frequently, surgical interventions are performed in the anterior maxillary region, such as dental implant placements, removal of impacted canines and also removal of cysts and tumors. Thus, the knowledge of noble anatomical structures present in this region is essential for the treatment to be successful. ${ }^{3,4}$

Conventional imaging exams have limitations to identify some intraosseous structures due to overlapping of anatomic structures. ${ }^{5}$ To observe intraosseous structures, three

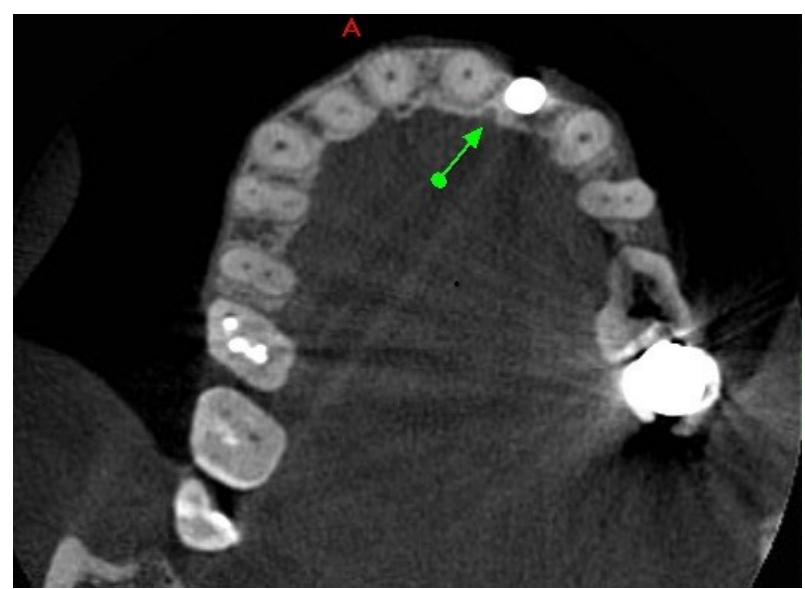

Figure 1 | Axial view

Computed Tomography Cone Beam image - Gendex CB 500. Green arrow points out the CS presence. dimensional radiography technique is more convenient to assess anatomic details. Thus, Cone Beam Computed Tomography (CBCT) images are useful and provide a great support in preoperative recognition of anatomical variations, since it allows evaluating anatomical structures in three plans, showing the precise location, diameter of the canal and proximity to other anatomical structures. ${ }^{6}$

In this report, we describe a prosthodontic rehabilitation by implant, wherein the CS is very close to dental implant planned area. Because of this proximity, it represents a greater risk for superior alveolar nerve injury.

\section{CASE REPORT}

A 57-year-old woman was treated at the private Oral Maxillofacial Imaging Center in Avaré, São Paulo, Brazil. The CBCT exam (Gendex CB50o) was requested by a dentist for one year, following-up a dental implant installed in region 22. Clinically, there were no signs of complications or symptoms. However, it was observed through a trans-axial view that the outer cortex of the canal was in close proximity from the dental implant (Tomography Figures 1-3

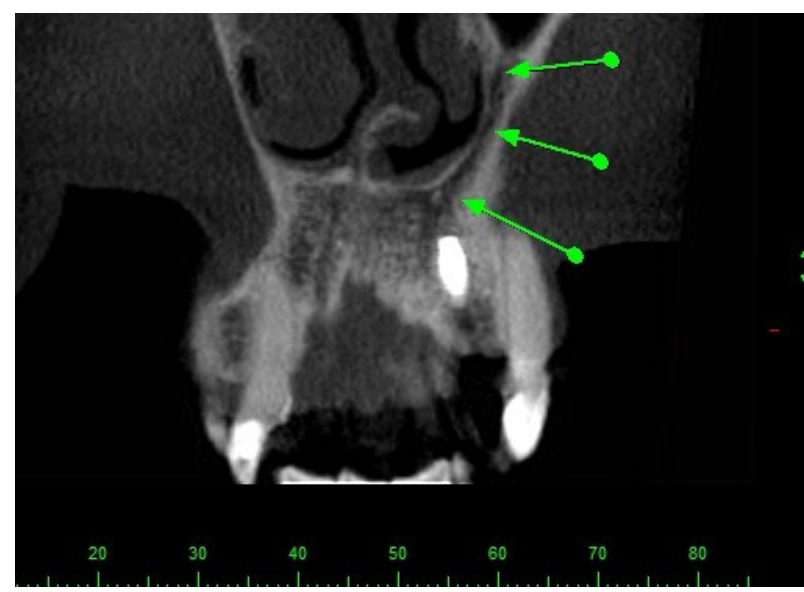

Figure 2 | Coronal view

Computed Tomography Cone Beam image - Gendex CB 500. Green arrow describes the CS path. 


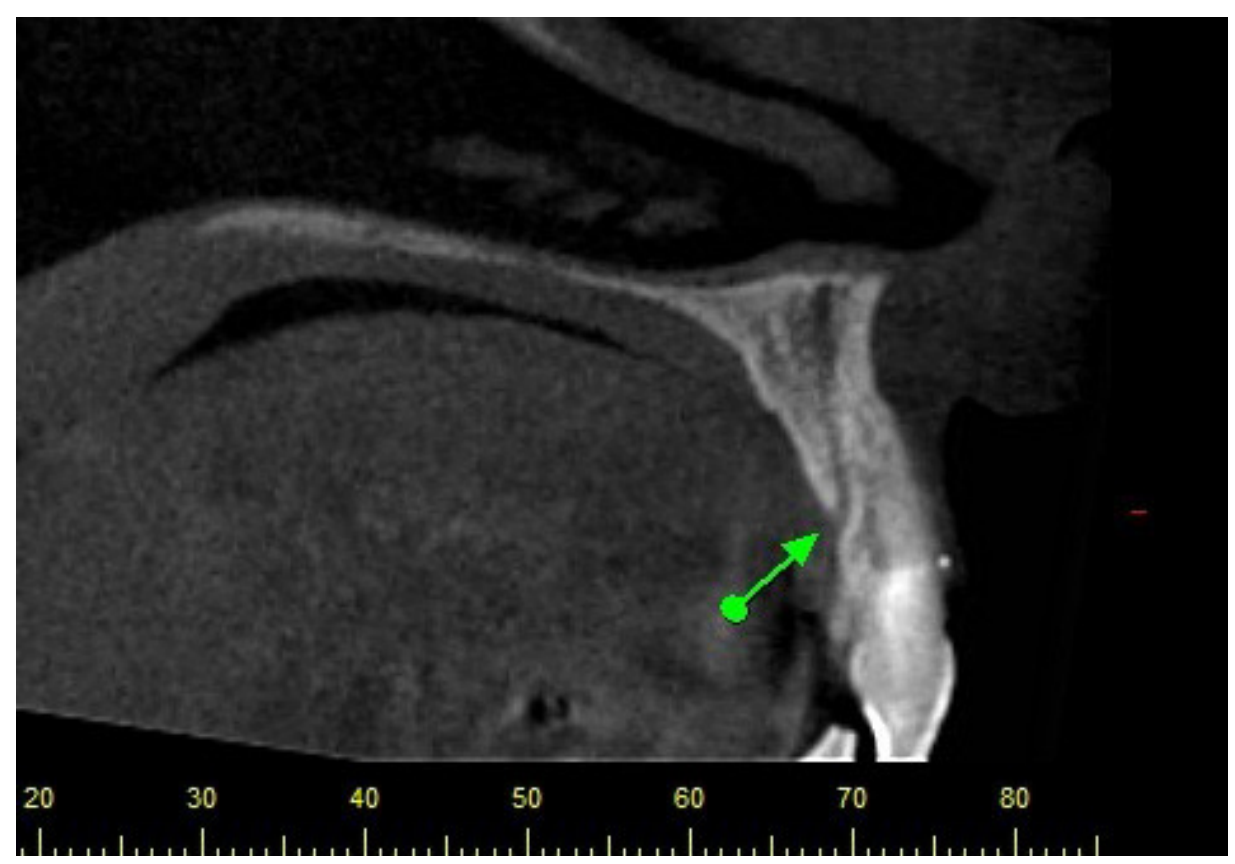

Figure 3 | Sagittal view

Computed Tomography Cone Beam image - Gendex CB 500.

Green arrow points out the CS exit.

The CS was observed unilaterally on the left side, in the middle third of the anterior maxillary sinus and lateral nasal cavity, downward and curved medially, with an oblique trajectory which

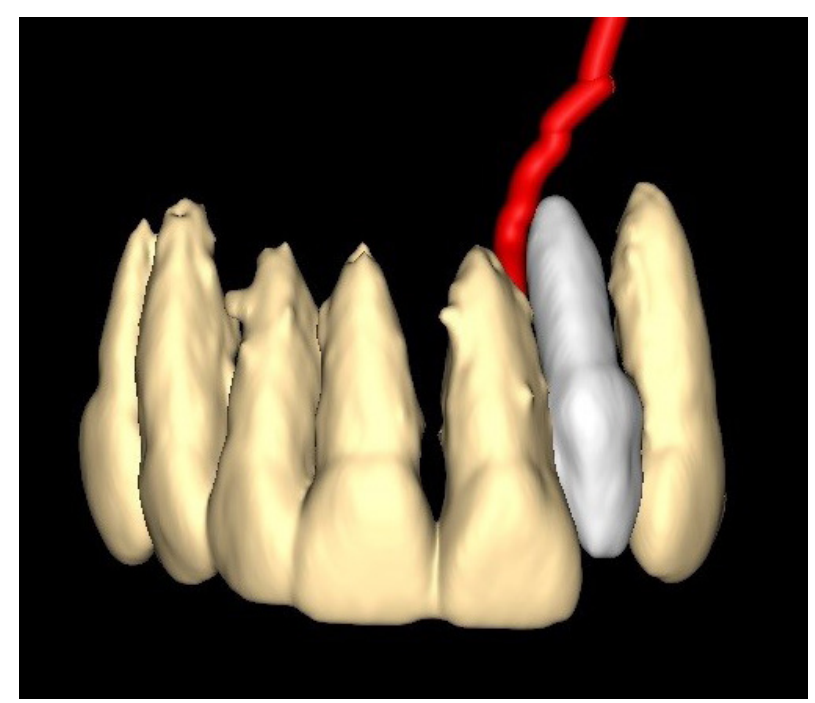

Figure 4 | Coronal View

$3 \mathrm{D}$ reconstruction of the proximity of the Canalis Sinuosus with the apical portion of the implant. could be observed in close proximity to the third apical region of dental implant that was placed in the area of region 22 (3D RECONSTRUCTION Figures 4 and 5).

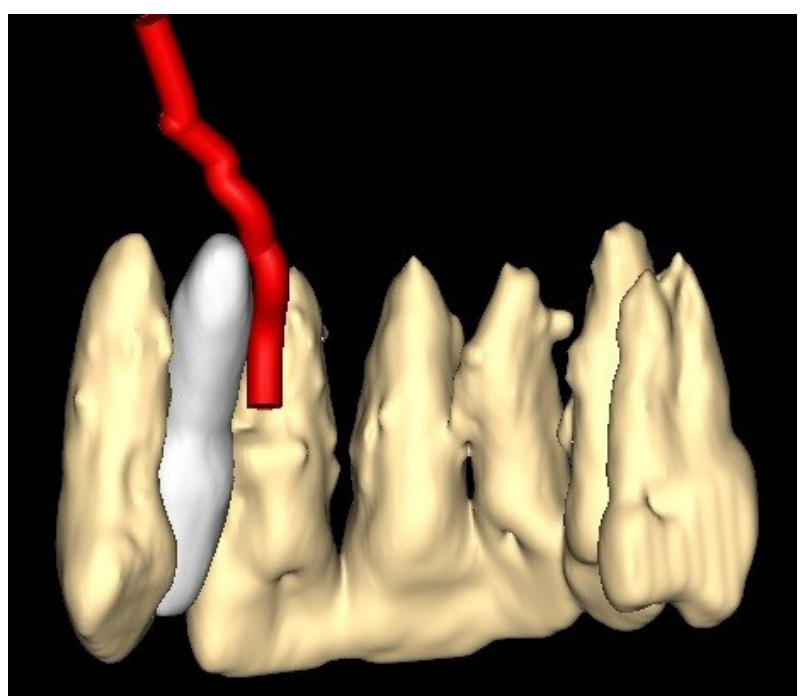

Figure 5 | Palatine View

3D reconstruction: note the proximity of the CS with the apical portion of the implant. 
The exit of CS was identified and it was in accordance with the schematic representation described by Oliveira-Santos et al.7, between central incisor and lateral incisor region.

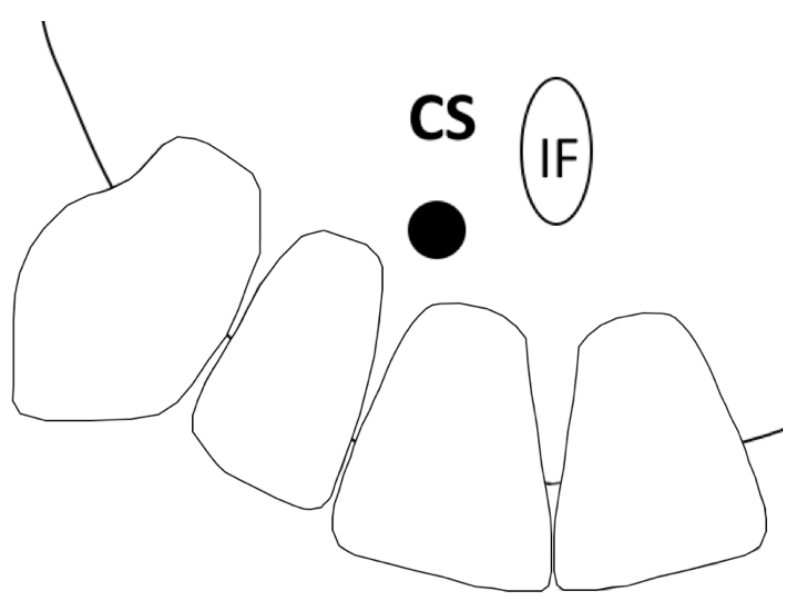

Figure 6 | The exit of CS was in the central incisor and lateral incisor region

The adapted schematic representation described by Oliveira-Santos et al. 2013

\section{DISCUSSION}

The literature is controversial defining the CS. The majority hold on to the position that the CS is an anatomical variation. ${ }^{1,2,6-8}$ However, some authors describe it as a common anatomical structure. ${ }^{9}$ Regardless of the anatomical classification, the professional must consider this structure in surgical planning, since many surgical procedures are performed in the anterior maxilla.

To warn and to aware surgeons of the importance of identifying the anatomical variations, Oliveira-Santos et al. ${ }^{7}$ described seven possible emergency sites of CS in the hard palate: Central incisors region; between central and lateral; lateral incisors region; canine region; first premolar region; lateral to incisive foramen and posterior to incisive foramen. ${ }^{7}$ Song et al. showed that the canine to premolar region is the most appropriate donor site for periodontal plastic surgery. ${ }^{10}$
Even though our case presented the exit of CS between central and lateral region, the anterior maxillary region still requires special attention for surgical interventions, since this region presents possible emergency sites of the CS.

It is important to emphasize that $\mathrm{CBCT}$ examinations are essential for surgical planning, bearing in mind that such procedures allow detecting noble structures poorly visualized on conventional radiographs. Thus, the CS identification becomes an important step of the surgical planning in the anterior maxilla.

\section{CONCLUSION}

The anatomic variation such as CS can be detected by CBCT exams and it is important to note that such exams are also highly recommended for surgical planning procedures to the anterior maxilla, in order to preserve noble anatomical structures.

\section{REFERENCES}

1. Jones FW. The anterior superior alveolar nerve and vessels. J Anat. 1939 Jul;73(Pt 4):583-91.

2. Neves FS, Crusoé-Souza M, Franco LC, Caria PH, Bonfim-Almeida P, Crusoé-Rebello IM. Canalis sinuosus: a rare anatomical variation. Surg Radiol Anat. 2012 Aug;34(6):563-6. doi: 10.1007/s00276-011-0907-6.

3. Mraiwa N, Jacobs R, Van Cleynenbreugel J, Sanderink G, Schutyser F, Suetens P, et al. The nasopalatine canal revisited using 2D and 3D CT imaging. Dentomaxillofac Radiol. 2004 Nov;33(6):396-402. doi: http://dx.doi.org/10.1259/ $\mathrm{dmfr} / 53801969$.

4. Liang X, Jacobs R, Lambrichts I. An assessment on spiral CT scan of the superior and inferior genial spinal foramina and canals. Surgical and Radiologic Anatomy. 2006 Mar;28(1):98-104. doi: 10.1007/s00276-005-0055-y

5. Kohavi D. Demonstration of unusually wide artery in the maxillary alveolar bone using a reformatting program of computed tomography: a case report. Int J Oral Maxillofac Implants. $1994 \mathrm{Jul} /$ Aug;9(4):444-8.

6. Wanzeler AMV, Marinho CG, Junior SMA, Manzi FR, Tuji FM. Anatomical study of the canalis sinuosus in 100 cone beam computed tomography examinations. Oral Maxillofac Surg. 2015 Mar;19(1):49-53. doi: 10.1007/s10oo6-014-0450-9. 
7. Oliveira-Santos C, Rubira-Bullen IRF, Monteiro SAC, León JE, Jacobs R. Neurovascular anatomical variations in the anterior palate observed on CBCT images. Clin Oral Implants Res. 2013 Sep;24(9):1044-8. doi: 10.1111/j. 1600-0501.2012.02497.x.

8. Manhães Júnior LRC, Villaça-Carvalho MFL, Moraes MEL, Lopes SLP de C, Silva MBF, Junqueira JLC. Location and classification of Canalis sinuosus for cone beam computed tomography: avoiding misdiagnosis. Braz Oral Res. 2016;30(1):e49. doi: 10.1590/1807-3107BOR-2016.vol30.0049.
9. Torres MGG, Faro Valverde L, Vidal MTA, Crusoé-Rebello IM. Branch of the canalis sinuosus: a rare anatomical variation a case report. Surg Radiol Anat. 2015 Sep;37(7):879-81. doi: 10.1007/s00276-015-1432-9.

10. Song JE, Um YJ, Kim CS, Choi SH, Cho KS, Kim CK, et al. Thickness of Posterior Palatal Masticatory Mucosa: The Use of Computerized Tomography. J Periodontol. 2008 Mar;79(3):406-12. doi: 10.1902/ jop.2008.070302. 